\title{
A causative matrix approach for measuring temporal structural changes caused by globalization in Latvian economy
}

\author{
Juris Hāzners ${ }^{1, *}$, Elita Benga ${ }^{1}$ \\ ${ }^{1}$ Institute of Agroresources and Economics (AREI), Department of Economics, Riga, Latvia
}

\begin{abstract}
.
Research background: globalization processes affect the economies mainly with intensified foreign trade flows which have an impact of all industries including also sectors that operate mainly in domestic markets. Identifying the structural changes in economy sectors is crucial for the selection of the future policy options.

Purpose of the article: the objective of the research is the estimation of the structural changes in Latvian economy by analyzing the structural changes in sector output over the period from 2006 to 2014.

Methods: the left causative matrix method allows for the evaluation of the contributions of economy sectors to other sectors and supply within the sector. By adding the changes in sector output multipliers which capture the changes in final demand, overall changes in the structure of sector output can be estimated. After the obtaining these indicators, sectors can be clustered based upon the change ratios.

Findings \& Value added: research results show that none of the sectors has performed positively in every aspect in terms of output externalization, importance for other sectors or contributions to final demand. Manufacture of textiles, wearing apparel and leather products is a single sector with increased externalization and importance for other sectors, while it's contribution to final demand has slightly declined. Agriculture and fishing along with number of manufacturing sectors has shown increased ratios with respect to other sectors and final demand. For sectors with increased internalization, the importance of other sectors and final demand has declined. In general, increased internalization should be considered alarming as it points to lower competitiveness of products forming sector output.
\end{abstract}

Keywords: structural changes; left causative matrix; output multipliers; Leontief framework

JEL Classification: $C 67 ; E 17$

\footnotetext{
* Corresponding author: juris.hazners@arei.lv
} 


\section{Introduction}

Structural economic changes are defined as temporal changes between economic sectors [1]. For policy makers in development planning, the estimation of mutual interdependence of sectors is an issue of utmost importance. As stated by Diamond, boosting the development in sectors with comparatively high interindustry linkages would trigger the changes in final demand that induce several rounds of economy-wide effects [2]. Structural changes over a certain period of time can be effectively analyzed by use of input-output framework. Input-output models have been extensively used to compare the structure of output since 1950s after the pioneer research of Leontief [3] later followed by ten Raa [4], Lahr [5] and Oosterhaven and Polenske [6]. The possible extensions of input-output analysis including environmental aspects are discussed by Jackson [7] The research of the structural changes based upon these models intensified after the 1980 with studies of Chenery [8] and Rose and Miernyk [9]. The causative matrix approach identifies not only the contributions of particular sectors to the whole economy, but it also reveals intersectoral relationships. The term "causative" first was chosen by Rogerson and Plane [10]. The extended approach suggested by Mattas and Shrestha [11] include sectoral elasticities. Input-output multipliers calculated according to Miller and Blair [12] are the most commonly used measures for estimating the impact of changes in final demand on the whole economy. The concept of multiplier effects is described by ten Raa [4]. However, multipliers neglect the relative size of a particular sector with respect to the total economy. Moreover, as stated by Dietzenbacher [13] they might lead to biased estimations. The problem of overestimation or underestimation of the true multiplier values is addressed by Jansen [14]. Oosterhaven and Stelder [15] proposed the concept of "net" multipliers as opposed to "standard" multipliers. However, this concept is by de Mesnard [16]. Output elasticities reveal the percentage change in total output in the economy due to percentage changes in the final demand of particular sector. The most comprehensive analysis of structural changes by Ciobanu et.al. [17] combines the use of input-output multipliers, input-output elasticities, causative matrix and decomposition of structural change. The combined approach applied in a study with output elasticities and left causative matrix has its limitations as the changes in the composition of the final demand, such as household, government and export demand as well as gross fixed capital formation are not accounted for.

\section{Materials and methods}

The causative-matrix method to analyze changes over time in country's economy is based on matrix transformations. Given two transition matrices, one is transformed into another by a left multiplication of the first matrix. In the context of input-output economic framework, the method is considered demand-driven. The core principles were developed by Jackson et. al. [1]. The method was further complemented by de Mesnard [18]. The causative matrix method is an extension to Input-Output (I-O) analysis to evaluate the change between two matrices. If simple multipliers are used, only the contributions of economic sectors to the whole economy can be identified. The causative matrix method allow for also focusing on the intersectoral relationships. The method is based on the Leontief inverse matrix. The transition matrix (standardized Leontief inverse), $\mathrm{K}$, is computed by the formula:

$$
K=Z M^{-1}
$$


where Z - Leontief inverse (Total Requirements matrix); M - diagonal matrix whose elements equal the sum of the jth column of $\mathrm{Z} ; \mathrm{K}$ - transition matrix (standardized Leontief inverse).

As the transition matrices are required to have column sums equal to 1 , the cells in each column of the Leontief inverse are normalized by their respective column sums. Such a normalization standardizes the changes in magnitudes of output multipliers. Hence, the analysis focuses upon the relative influences of each sector on all other sectors. The linkage between transition matrices in given two time periods, $t$ and $t+1$, are expressed by the formula:

$$
K_{t+1}=C K_{t}
$$

where $\mathrm{C}$ - causative matrix; $\mathrm{K}_{\mathrm{t}}$ - transition matrix at year $\mathrm{t} ; \mathrm{K}_{\mathrm{t}+1}$ - transition matrix at year $\mathrm{t}+1$.

The causative matrix, $\mathrm{C}$, is defined as follows:

$$
C=K_{t+1} K_{t}^{-1}
$$

The causative matrix explains the change between the transition matrices by the interpretation of its elements, diagonal element sums and row sums. It is also called left causative matrix. If there is a reduction in sector i's contribution to sector $j$ 's output multiplier due to the presence of sector $\mathrm{k}$, the corresponding element of the matrix is negative. All column sums of $\mathrm{C}$ equal 1. Row sums less than 1 indicate smaller contributions to output multipliers, i.e. the corresponding sectors recording smaller impacts when final demands in other sectors change (and vice versa in the case of row sums greater than 1). Negative deviations of the diagonal elements of sectors from 1 imply decreased relative internalization of their own final demand output impacts (and vice versa in the case of positive deviations of the diagonal elements from 1). As stated by Jackson et.al. [1], a large diagonal element indicates that final demand impacts of sector $i$, relative to others, are increasingly being internalized within the sector. A large off-diagonal element indicates an increasing proportionate importance of final demand deliveries from sector $\mathrm{j}$ in stimulating output of sector $i$, either directly from deliveries from sector $\mathrm{j}$ that satisfy final demand, or relative to the impacts of final demand deliveries from all other sectors.

The advantages of the causative matrix approach are determined by capturing both the direct changes in interactions and the relative changes due to the presence of other sectors.

Although I-O multipliers are the most common measures for estimating the economywide impacts of changes in final demand, the relative size of a sector in a region's economy is not accounted for. This deficiency of multipliers can be avoided by use of I-O elasticities as indicators for estimating sectoral potentials on the growth of an economy proposed by Mattas and Shrestha [11]. I-O elasticities expose the percentage change in total output, income or employment of the economy due to percentage changes in the final demand of each sector of region's economy. Therefore, elasticities provide better insights than multipliers of the impacts of sectoral changes on the economy.

The output elasticity for sector $\mathrm{j}$ is estimated as:

$$
O E_{j}=\sum_{i=1}^{n} z_{i j}\left(y_{j} / X\right)
$$

where $\mathrm{OE}_{\mathrm{j}}$ - output multiplier of sector $\mathrm{j} ; \mathrm{z}_{\mathrm{ij}}$ - element of total requirements matrix; $\mathrm{y}_{\mathrm{j}}$ final demand of the sector $\mathrm{j}$; $\mathrm{X}$ - total regional output.

Output elasticity shows the percentage change in a region's total output associated with a one percent change in final demand sales by sector $\mathrm{j}$. 
The Leontief Inverse matrices for Latvia in 2006 and 2014 are calculated based upon the tables retrieved from World Input Output Database (WIOD) [19], covering 54 industry sectors.

\section{Results and discussion}

After constructing the Leontief inverse matrices, the transition matrices (standardized Leontief inverse), are computed by the formula (1) for 2006 and 2014. Based on these two matrices, the left causative matrix is calculated by formula (3). Output elasticities for industry sectors are calculated by formula (4) for all 54 industry sectors. The 54 industry sectors are ranked by their output and 28 sectors are selected with the aggregate output about $90 \%$ of total regional output. The values of percentage changes in diagonal elements and row sums of the left causative matrix along with the percentage changes in output elasticities are shown in Table 1.

Table 1. Sectoral structural changes for 2006-2014 based on left causative matrix results and output elasticities (percentages)

\begin{tabular}{|l|c|c|c|}
\hline \multirow{2}{*}{ Sector } & \multicolumn{2}{c|}{$\mathbf{2 0 1 4}$ compared to 2006 } \\
\cline { 2 - 4 } & $\begin{array}{c}\text { Diagonal } \\
\text { elements }\end{array}$ & Row sums & $\begin{array}{c}\text { Output } \\
\text { elasticities }\end{array}$ \\
\hline $\begin{array}{l}\text { Crop and animal production, hunting and related service } \\
\text { activities }\end{array}$ & -8.62 & -11.76 & 1.10 \\
\hline Forestry and logging & 0.41 & 2.79 & 0.31 \\
\hline $\begin{array}{l}\text { Manufacture of food products, beverages and tobacco } \\
\text { products }\end{array}$ & 0.57 & -14.06 & -1.91 \\
\hline $\begin{array}{l}\text { Manufacture of textiles, wearing apparel and leather } \\
\text { products }\end{array}$ & -1.15 & 0.38 & -0.89 \\
\hline $\begin{array}{l}\text { Manufacture of wood and of products of wood and cork, } \\
\text { except furniture; manufacture of articles of straw and } \\
\text { plaiting materials }\end{array}$ & -1.68 & -3.21 & 1.13 \\
\hline Manufacture of other non-metallic mineral products & 2.92 & 7.05 & 0.40 \\
\hline Manufacture of basic metals & -3.53 & -4.14 & -0.46 \\
\hline $\begin{array}{l}\text { Manufacture of fabricated metal products, except } \\
\text { machinery and equipment }\end{array}$ & 0.74 & 2.60 & 0.21 \\
\hline Electricity, gas, steam and air conditioning supply & 2.25 & 60.95 & 1.27 \\
\hline Construction & 1.96 & 7.44 & -4.23 \\
\hline $\begin{array}{l}\text { Wholesale and retail trade and repair of motor vehicles } \\
\text { and motorcycles }\end{array}$ & -4.70 & -15.77 & -0.13 \\
\hline $\begin{array}{l}\text { Wholesale trade, except of motor vehicles and } \\
\text { motorcycles }\end{array}$ & -7.97 & -16.43 & 1.07 \\
\hline Retail trade, except of motor vehicles and motorcycles & 4.50 & -36.23 & -1.12 \\
\hline Land transport and transport via pipelines & -2.32 & -41.20 & 0.33 \\
\hline Air transport & -4.68 & -2.83 & 0.46 \\
\hline $\begin{array}{l}\text { Warehousing and support activities for transportation } \\
\text { Mand }\end{array}$ & 1.99 & -11.03 & 0.91 \\
\hline
\end{tabular}




\begin{tabular}{|l|c|c|c|}
\hline Accommodation and food service activities & 1.43 & 3.97 & 0.30 \\
\hline Telecommunications & -7.94 & -13.83 & -0.17 \\
\hline $\begin{array}{l}\text { Computer programming, consultancy and related } \\
\text { activities; information service activities }\end{array}$ & 12.73 & 34.41 & 0.68 \\
\hline $\begin{array}{l}\text { Financial service activities, except insurance and pension } \\
\text { funding }\end{array}$ & -3.26 & -3.27 & -0.01 \\
\hline Real estate activities & 3.35 & 2.56 & -0.33 \\
\hline $\begin{array}{l}\text { Legal and accounting activities; activities of head offices; } \\
\text { management consultancy activities }\end{array}$ & 17.40 & 15.23 & 0.05 \\
\hline $\begin{array}{l}\text { Advertising and market research } \\
\text { Administrative and support service activities }\end{array}$ & -7.76 & -16.66 & 0.20 \\
\hline $\begin{array}{l}\text { Public administration and defense; compulsory social } \\
\text { security }\end{array}$ & -2.49 & -4.31 & -0.17 \\
\hline Education & 1.10 & 0.57 & 0.05 \\
\hline Human health and social work activities & -0.52 & -0.45 & 0.19 \\
\hline Other service activities & 2.11 & 3.82 & -0.07 \\
\hline $\begin{array}{l}\text { Crop and animal production, hunting and related service } \\
\text { activities }\end{array}$ & -8.62 & -11.76 & 1.10 \\
\hline
\end{tabular}

In $57 \%$ of the economy sectors an "internalization" is seen over the period. It means that in these sectors supply within the sector has increased. At the same time, $52 \%$ of the sectors have increased their importance as suppliers to other sectors. Only in 39\% of economy sectors have increased their ability to generate overall output impacts across the economy.

The selected sectors are mapped on the scatterplot diagram (Fig 1).

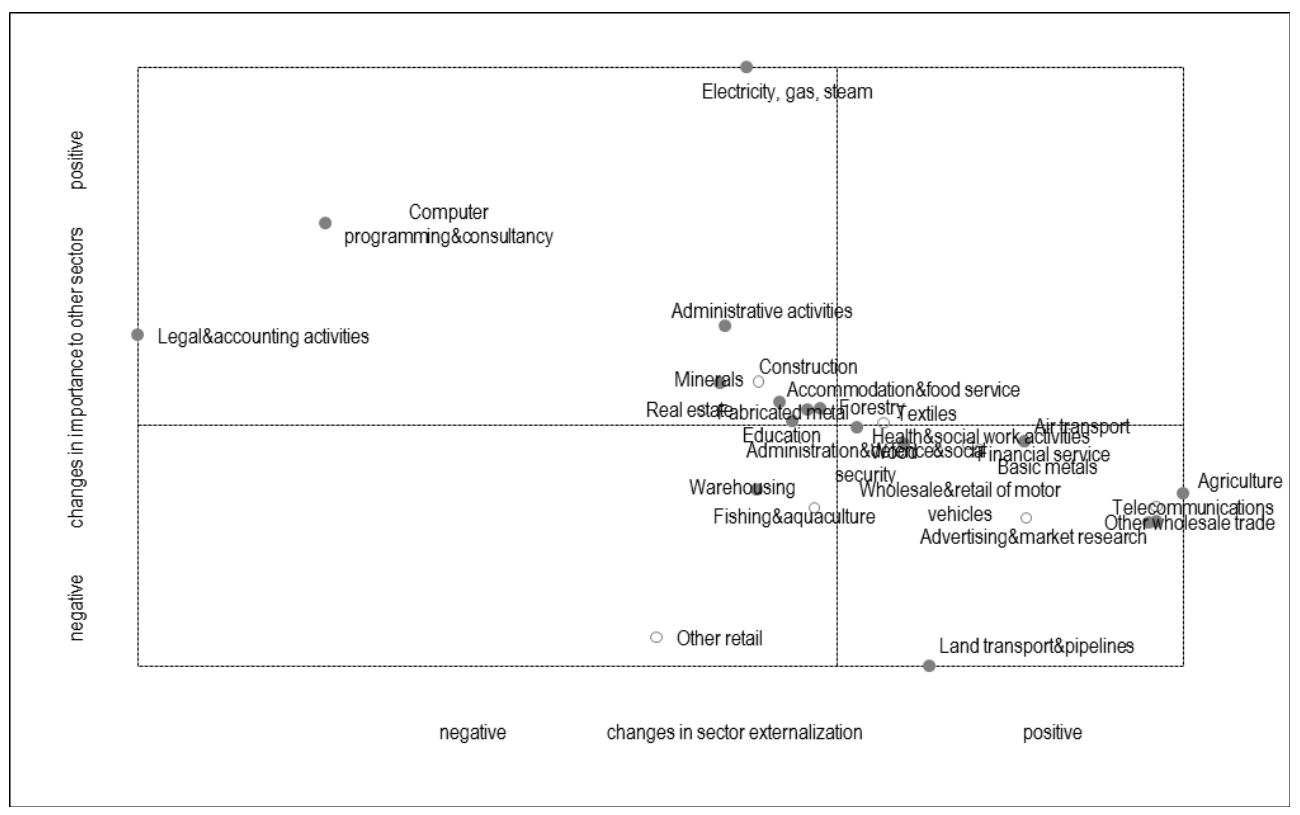


Fig. 1. Positioning of the sectors based on the structural changes

Sums of diagonal elements of the left causative matrix plotted on the horizontal axis show the change in sector "externalization". Row sums of the left causative matrix plotted on the vertical axis show the change in the sector's importance for other sectors. Marker fill (colored or empty) indicate the change in sectoral output elasticities (positive or negative, respectively).

The majority of the selected sectors lie within the lower right quadrant. It means that their importance as suppliers within the sector and to other sectors has declined simultaneously. The possible cause of this can be the increase in final demand. For example, significant increase in cereal exports in agriculture has contributed to the relative decline in domestic supplies both within the agriculture and to food processing. Increased "internalization" along with the growth in importance to other sectors show the relative increase in respective supplies from legal and accounting sectors as well as form computer programming and consultancy.

All industry sectors can be clustered based on these three variables.

The largest cluster with 17 sectors is characterized by increased internalization, increased importance to other sectors and improved ability to generate additional output in the economy as a whole. These include forestry, fishing, mining, mineral products, fabricated metal products, electrical equipment, motor vehicles, all utilities, postal and courier activities, accommodation and food service, computer programming, consultancy and related activities, information service activities, legal and accounting activities; activities of head offices; management consultancy activities, scientific research and development, other professional, scientific and technical activities; veterinary activities, administrative and support service activities, education.

Manufacture of wood, manufacture of paper, printing and reproduction of recorded media, manufacture of chemicals, manufacture of computer, electronic and optical products, manufacture of other machinery and equipment, water collection, treatment and supply, wholesale trade, except of motor vehicles and motorcycles, land transport and transport via pipelines, air transport, insurance, reinsurance and pension funding, except compulsory social security, advertising and market research are the sectors with increased externalization, lower importance to other sectors and improved ability to generate additional output in the economy as a whole.

Manufacture of rubber and plastic products, manufacture of basic metals, manufacture of other transport equipment, wholesale and retail trade and repair of motor vehicles and motorcycles, motion picture, video and television program production, sound recording and music publishing activities; programming and broadcasting activities, telecommunications, financial service activities, except insurance and pension funding, public administration and defense; compulsory social security are the sectors with increased externalization, lower importance to other sectors and lower ability to generate additional output in the economy as a whole.

Sectors such as manufacture of coke and refined petroleum products, manufacture of basic pharmaceutical products and pharmaceutical preparations, construction, water transport, activities auxiliary to financial services and insurance activities, real estate activities, architectural and engineering activities; technical testing and analysis, other service activities are characterized by increased internalization, higher importance to other sectors and lower ability to generate additional output in the economy as a whole.

Manufacture of food products, beverages and tobacco products, manufacture of furniture; other manufacturing, retail trade, except of motor vehicles and motorcycles, publishing activities are the sectors with increased internalization, lower importance to other sectors and lower ability to generate additional output in the economy as a whole. 
Repair and installation of machinery and equipment, warehousing and support activities for transportation are two sectors where internalization has increased, the importance to other sectors has lowered and the ability to generate additional output in the economy as a whole has improved.

Manufacture of textiles, wearing apparel and leather products is the sole sector where externalization has increased, the importance to other sectors has grown and the ability to generate additional output in the economy as a whole has declined.

\section{Conclusions}

None of the sectors has simultaneously "externalized", increased its importance to other sectors or improved the ability to influence the total output in economy from 2006 to 2014.

Manufacture of textiles, wearing apparel and leather products is the only sector that has both "externalized" and increased its importance to other sectors. At the same time, the ability of the sector to influence the total output in economy from 2006 to 2014 has declined.

More then half of the economy sectors has experienced an "internalization" with relatively more of the supply remaining within the sector. Out of these, food processing, manufacture of furniture and publishing activities are the sectors whose importance as suppliers to other sectors has declined along with the ability to generate additional output in economy in general.

The structural changes observed have to be considered by policy makers and detailed analysis of the underlying causes has to be carried out. The analysis should focus on the changes in final demand both in terms of volumes and structure.

\section{References}

1. Jackson, R.W., Rogerson, P., Plane, D.A. (1974). A causative matrix approach to interpreting structural change. Economic Systems Research, 37, 259-269.

2. Diamond, J. (1974). The analysis of structural constraints in developing economies: a case study. Oxford Bulletin of Economics and Statistics, 36, 95-108.

3. Leontief, W. (1993). Input-output-analysis as an alternative to conventional econometric-models. Mathematical Social Science, 25(3), 306-307.

4. ten Raa, T. (2005). The Economics of Input-Output Analysis. Cambridge University Press, 2005.

5. Lahr, M.L. (2010). Input-output analysis: foundations and extensions, 2nd edition. Environment and Planning 37(2), 382-383.

6. Oosterhaven, J., Polenske, K.R. (2009). Modern regional input-output and impact analyses. Handbook of Regional Growth and Development Theories. Edward Elgar Publishing.

7. Jackson, R.W. (2003). Input-output analysis: Frontiers and extensions. Journal of Regional Science, 43(4), 791-794.

8. Chenery, H.B. (1980). Interactions between industrialization and exports. American Economic Review, 70, 281-287.

9. Rose, A., Miernyk, W. (1989). Input-output analysis: the first fifty years. Economic Systems Research, 1, 229-271.

10. Rogerson, P.A., Plane, D.A. (1984). Modeling temporal change in flow matrices. Regional Sciences, 54(1), 147-164. 
11. Mattas, K., Shrestha, C.M. (1991). A new approach to determining sectoral priorities in an economy: input-output elasticities. Applied Economics, 23(1), 247-254.

12. Miller, R.E., Blair, P.D. (1985). Input-Output Analysis: Foundations and Extentions. Prentice-Hall, Inc, New Jersey.

13. Dietzenbacher, E. (2006). To bias or not to bias? International Journal of Regional Science, 46(4), 773-786.

14. Jansen, P.S.M.K. (1994). Analysis of multipliers in stochastic input-output model. Regional Science and Urban Economics, 24(1), 55-74.

15. Oosterhaven, J., Stelder, D. (2002). Trade, network and hierarchies: modeling regional and interregional economies. Journal of Regional Science, 42(3), 533-543.

16. de Mesnard, L. (2007). A critical comment on Oosterhaven-Stelder net multipliers. Annals of Regional Science, 41(2), 249-271.

17. Ciobanu, C., Mattas, K., Psaltopoulos, D. (2004). Structural changes in less developed areas: an input-output framework. Regional Studies, 38(6), 603-614.

18. de Mesnard, L. (2000). Bicausative matrices to measure structural change: Are they a good tool? Annals of Regional Science, 34, 421-449.

19. WIOD. (2017). World Input-Output Database: National Input-Output Tables. Retrieved from: http://www.wiod.org/database/niots16 